\title{
XK Gene
}

National Cancer Institute

\section{Source}

National Cancer Institute. XK Gene. NCI Thesaurus. Code C148001.

This gene may play a role in sodium-dependent transport of neutral amino acids or peptides. 